\title{
Memantine Improves Cognition and Reduces Alzheimer's-Like Neuropathology in Transgenic Mice
}

\author{
Hilda Martinez-Coria, ${ }^{*}$ Kim N. Green, ${ }^{*}$ \\ Lauren M. Billings, ${ }^{*}$ Masashi Kitazawa, ${ }^{*}$ \\ Miriam Albrecht, ${ }^{\dagger}$ Gerhard Rammes, $^{+}$ \\ Chris G. Parsons, ${ }^{\dagger}$ Sandeep Gupta, ${ }^{\S}$ \\ Pradeep Banerjee, ${ }^{\S}$ and Frank M. LaFerla* \\ From the Department of Neurobiology and Behavior," University \\ of California, Irvine, Irvine, California; Merz Pharmaceuticals, ${ }^{\dagger}$ \\ Frankfurt, Germany; the Department of Anaesthesiology, \\ Technical University, Munich, Germany; and the Department of \\ Pharmacology, ${ }^{\S}$ Forest Research Institute, Jersey City, New Jersey
}

\begin{abstract}
Memantine is an $N$-methyl-D-aspartate receptor antagonist that is approved for the treatment of moderate to severe Alzheimer's disease (AD). In this study, three groups of triple-transgenic (3xTg-AD) mice with differing levels of $\mathrm{AD}$-like pathology $(6,9$, and 15 months of age) were treated for 3 months with doses of memantine equivalent to those used in humans. After the treatment, memantine-treated mice had restored cognition and significantly reduced the levels of insoluble amyloid- $\beta(A \beta), A \beta$ dodecamers $(A \beta * 56)$, prefibrillar soluble oligomers, and fibrillar oligomers. The effects on pathology were stronger in older, more impaired animals. Memantine treatment also was associated with a decline in the levels of total tau and hyperphosphorylated tau. Finally, memantine pre-incubation prevented $\mathbf{A} \beta$-induced inhibition of long-term potentiation in hippocampal slices of cognitively normal mice. These results suggest that the effects of memantine treatment on AD brain include disease modification and prevention of synaptic dysfunction. (Am J Pathol 2010, 176:870-880; DOI: 10.2353/ajpath.2010.090452)
\end{abstract}

Alzheimer's disease (AD) is the most common progressive neurodegenerative disorder afflicting the elderly, ${ }^{1,2}$ characterized by a progressive and irreversible loss of neurons in specific brain regions. The disease gradually affects memory, learning abilities, and language skills, causes behavioral and personality changes, interferes with the individual's ability to perform daily activities, and ultimately leads to death. ${ }^{3,4}$ At the neuropathological level, the AD brain is marked by extracellular amyloid plaques, mainly composed of aggregated amyloid- $\beta$ $(A \beta)$ peptides and by intracellular neurofibrillary tangles, composed of the hyperphosphorylated tau protein, ${ }^{4,5}$ along with multiple secondary pathologies such as inflammation, oxidative stress, and ionic imbalances.

Four drugs are currently approved by the Food and Drug Administration for the treatment of AD. Of these, three are acetylcholinesterase inhibitors, ${ }^{6}$ whereas the fourth, memantine (1-amino-3,5-dimethyl-adamantane), is an uncompetitive, moderate-affinity antagonist of $\mathrm{N}$ methyl-D-aspartate (NMDA) receptors. ${ }^{7-9}$

Animal models of $A D$ have been invaluable for elucidating the molecular mechanisms of the disease, as well as for evaluating potential therapeutic interventions. Triple transgenic $(3 \times T g-A D)$ mice, which harbor PS1 ${ }_{M 146 V}$ knockin alleles and $\mathrm{APP}_{\mathrm{Swe}}$, and tau $\mathrm{P}_{\mathrm{P} 01 \mathrm{~L}}$ transgenes, develop age-dependent and region-specific $A \beta$ and tau aggregations that closely mimic the disease progression in humans. ${ }^{10}$ The $3 \times T g-A D$ mice also develop age-related cognitive decline and impairment in synaptic plasticity, including deficits in long-term potentiation (LTP), a neuronal phenomenon that is thought to underlie learning and memory. ${ }^{11-13}$ In the hippocampus, LTP is dependent on NMDA receptors (NMDARs), which function as calciumpermeable ion channels. ${ }^{14}$ Overactivation of NMDARs results in excessive calcium influx, which can trigger a variety of processes that lead to necrosis, apoptosis, or denditric/synaptic damage. ${ }^{8} \mathrm{~A} \beta$ peptides can bind to and activate NMDARs, which results in internalization of the receptor-A $\beta$ complex, ${ }^{15}$ increased calcium influx, ${ }^{16,17}$ formation of reactive oxygen species, ${ }^{16}$ and synapse loss. ${ }^{17} \mathrm{~A} \beta$ can also induce internalization of NMDARs alone. ${ }^{18}$ In addition, excessive NMDAR activity has been reported to increase the hyperphosphorylation of tau. ${ }^{19}$ It has been suggested that $A \beta$ mildly activates normal NMDA receptor function, reducing postsynaptic

\footnotetext{
Supported by the Forest Research Institute.

Accepted for publication September 29, 2009

Supplemental material for this article can be found on http://ajp. amjpathol.org.

Address reprint requests to Frank M. LaFerla, Ph.D., Department of Neurobiology and Behavior, University of California, Irvine, 3400A Biological Sciences III, Irvine, CA 92697-4545. E-mail: laferla@uci.edu.
} 
potentiation via increased calcium influx, leading to cognitive impairments and, eventually, synaptic and neuronal loss. ${ }^{20}$

Memantine is thought to selectively block the excitotoxic effects associated with abnormal glutamatergic transmission, while allowing for the physiological transmission associated with normal cell functioning. ${ }^{8}$ Clinical trials have shown that memantine is an effective, safe, and well-tolerated treatment option for moderate to severe $A D .^{7,21}$ Its effects have been investigated in a large number of in vitro and in vivo studies, which indicate that memantine offers protection from neurotoxicity induced by $A \beta .^{22}$ Memantine has also been shown to improve cognitive and behavioral performance in different transgenic models of $A D,{ }^{23-25}$ but the details of the mechanism by which it leads to improved performance still remain to be elucidated. The purpose of this study was to investigate the effects of memantine on cognitive performance in 3xTg-AD mice, as well as the disease-modifying potential of memantine (ie, ability to reduce the brain levels of $A \beta$ and hyperphosphorylated tau) in this animal model. Our data suggest that memantine treatment of $A D$ may indeed produce disease-modifying effects.

\section{Materials and Methods}

\section{Compound Used}

Memantine (1-amino-3,5-dimethyl-adamantane) $\mathrm{HCl}$ was provided by Forest Laboratories, Inc., in a purity of $99.3 \%$.

\section{Animals and Treatment}

The derivation and characterization of the 3xTg-AD mice has been described elsewhere. ${ }^{10}$ Briefly, two independent transgenes encoding human $\mathrm{APP}_{\text {Swe }}$ and the human tau ${ }_{\text {P301L }}$ (both under control of the mouse Thy 1.2 regulatory element) were co-microinjected into single-cell embryos harvested from homozygous mutant $\mathrm{PS}_{\mathrm{M} 146 \mathrm{~V}}$ knockin (PS1-KI) mice. ${ }^{10}$ In this study, 6-, 9- and 15month-old homozygous 3xTg-AD mice, 10 per group (five male, five female); littermates or cousins, and agematched NonTg mice were treated for 3 months with vehicle only ( $2 \%$ sucrose in water; littermates or cousins) or a clinically relevant dose of memantine $(30 \mathrm{mg} / \mathrm{kg} /$ day), shown to produce a steady-state plasma drug level of approximately $1 \mu \mathrm{mol} / \mathrm{L}$ in mice. ${ }^{23,26}$ In clinical practice, a stable dose of $20 \mathrm{mg} /$ day memantine in patients with $A D$ produces a steady-state plasma drug level of approximately $0.5 \mu \mathrm{mol} / \mathrm{L} .{ }^{27,28}$ Memantine is known to block the NMDA receptors with an $I C_{50}$ of about 1 $\mu \mathrm{mol} / \mathrm{L}$, and it blocks synaptic plasticity (eg, LTP) only at much higher concentrations $\left({ }^{2} C_{50}=11.6 \mu \mathrm{mol} / \mathrm{L}\right)^{29,30}$ Based on our earlier work, ${ }^{10,13,31}$ the youngest group of animals (6 months old at the onset of the study) was expected to show intraneuronal $A \beta$ and somatodendritic tau accumulation by the end of the 3-month treatment, and was named the mild pathology group. The second age group (9 months old at the onset) was expected to accumulate extracellular $A \beta$ plaques and show signs of plaque-associated inflammation by the end of treatment, and was named the moderate pathology group. The oldest group of mice (15 months of age at the onset) was expected by the end of treatment to develop extensive $\mathrm{A} \beta$ plaque burden, along with signs of activated microglia and even stronger inflammation. All mice were given an unlimited access to food and water. The water consumption was measured twice per week. After the first week, we estimated that the daily consumption was stable $(8 \mathrm{ml} / 30 \mathrm{~g})$, and the memantine concentration was adjusted accordingly. Before and after the three months of treatment, the animals were tested on a battery of cognitive tasks, and at the end of testing the animals were sacrificed for neuropathological studies. Blood samples to determine the plasma levels of memantine were taken after the last behavioral task was performed.

\section{Behavioral Tests}

Hidden and cued platform Morris water maze training and testing were conducted as described previously. ${ }^{11}$ Mice were trained to swim to a circular clear Plexiglas platform (diameter, $14 \mathrm{~cm}$ ), submerged $1.5 \mathrm{~cm}$ beneath the water surface. The platform location was selected randomly for each mouse but was kept constant for each individual mouse throughout the training phase. The mice were subjected to four training trials a day for as many days as needed to reach the training goal of swimming to the submerged platform (escape latency) within $20 \mathrm{sec}-$ onds for mild and moderate pathology groups ( 7 days pretreatment and 8 days post-trained) and 8 days for the oldest group as criterion for stop training. Retention of the spatial training was assessed 1.5 hours (short-term memory) and 24 hours (long-term memory) after the last training session, by measuring the time the animals needed to cross the location of a platform that has been removed.

The object recognition task used is based on the spontaneous tendency of rodents to explore a novel object longer than a familiar one. ${ }^{32}$ On day 1 , the mice were allowed to familiarize themselves with the empty open field for 5 minutes. On day 2, they were subjected to a 5-minute exploration session of two identical, symmetrically placed objects A. Ninety minutes and 24 hours later, the animals were subjected to a 3-minute retention session where they were exposed to one object $A$ and to a novel object B (after 90 minutes) or object C (after 24 hours). The times of exploration were recorded, and an object recognition index (ORI) was calculated, such that ORI $=\left(t_{n}-t_{f}\right) /\left(t_{n}+t_{f}\right)$, where $t_{f}$ and $t_{n}$ represent times of exploring the familiar and novel objects, respectively.

Contextual learning and memory was evaluated using the passive inhibitory avoidance task, performed in the Gemini Avoidance System (San Diego Instruments, San Diego, CA). The training trial consisted of placing a mouse in the illuminated compartment of the device, and recording the time required for it to enter the dark compartment (baseline latency). On entering, the door between the two compartments was closed and the animal was immediately given an electric shock to the feet $(0.15$ $\mathrm{mA}, 1$ second). During the retention trials (conducted 1.5 
Table 1. Antibodies Used

\begin{tabular}{|c|c|c|c|c|c|c|}
\hline Antibody & Immunogen & Host & Application & $\begin{array}{c}\text { Stock } \\
\text { concentration }\end{array}$ & Dilution & Source \\
\hline $6 \mathrm{E} 10$ & aa $1-16$ of $A \beta$ & Mouse & WB & & $1: 1000$ & Signet \\
\hline APP CT20 & aa 751-770 of human APP & Rabbit & WB & & $1: 1000$ & Calbiochem \\
\hline$A \beta 40(C 49)$ & aa $35-40$ of $A \beta$ & Mouse & ELISA & & & $\begin{array}{l}\text { Drs. Cribbs and } \\
\quad \text { Vasilevko }\end{array}$ \\
\hline$A \beta 42(D 3)$ & aa 35-42 of $A \beta$ & Mouse & IHC, ELISA & & & $\begin{array}{l}\text { Drs. Cribbs and } \\
\quad \text { Vasilevko }\end{array}$ \\
\hline A11 & Prefibrillar oligomers & Rabbit & IB & & $1: 2000$ & Dr. Glabe \\
\hline $\mathrm{OC}$ & Fibrillar oligomers & Rabbit & IB & & $1: 2000$ & Dr. Glabe \\
\hline HT7 & aa $159-163$ of human tau & Mouse & WB & $200 \mu \mathrm{g} / \mathrm{ml}$ & $1: 5000$ & Pierce \\
\hline AT8 & Peptide containing phospho-S199/S202/T205 & Mouse & WB & $200 \mu \mathrm{g} / \mathrm{ml}$ & $1: 1000$ & Pierce \\
\hline AT180 & Peptide containing phospho-T231/S235 & Mouse & WB & $200 \mu \mathrm{g} / \mathrm{ml}$ & $1: 1000$ & Pierce \\
\hline AT100 & Peptide containing phospho-S212/T214 & Mouse & WB & $200 \mu \mathrm{g} / \mathrm{ml}$ & $1: 1000$ & Pierce \\
\hline AT270 & Peptide containing phospho-T181 & Mouse & WB & $200 \mu \mathrm{g} / \mathrm{ml}$ & $1: 1000$ & Pierce \\
\hline PHF-1 & Peptide containing phospho-S396/S404 & Mouse & WB & & $1: 5000$ & Dr. P. Davis \\
\hline p35/p25 & C terminus of human p35 & Rabbit & WB & $200 \mu \mathrm{g} / \mathrm{ml}$ & $1: 1000$ & $\begin{array}{l}\text { Santa Cruz } \\
\quad \text { Biotechnology }\end{array}$ \\
\hline GSK- $3 \alpha \beta$ & $\begin{array}{l}\text { Recognizes the } \sim 51 \text { GSK } 3 \alpha \text { and the } \sim 47 \mathrm{kd} \\
\text { GSK3 } \beta \text { proteins }\end{array}$ & Mouse & WB & & $1: 1000$ & Calbiochem \\
\hline $\begin{array}{l}\text { Phospho- } \\
\text { GSK-3 } \beta\end{array}$ & $\begin{array}{l}\text { Phosphoepitopes around ser9 of human } \\
\text { GSK3 } \beta\end{array}$ & Rabbit & WB & & $1: 1000$ & Cell Signaling \\
\hline BACE1 & aa $485-501$ of human BACE1 & Rabbit & WB & $1 \mu \mathrm{g} / \mu \mathrm{l}$ & $1: 1000$ & Calbiochem \\
\hline ADAM10 & aa 735-749 of mouse ADAM10 & Rabbit & WB & & $1: 1000$ & Calbiochem \\
\hline IDE & IDE of human origin & Rabbit & WB & $100 \mu \mathrm{g} / \mathrm{ml}$ & $1: 2000$ & $\begin{array}{l}\text { Santa Cruz } \\
\quad \text { Biotechnology }\end{array}$ \\
\hline Actin & C-terminal actin fragment (C11) & Rabbit & WB & & $1: 10000$ & Sigma-Aldrich \\
\hline
\end{tabular}

Calbiochem, San Diego, CA; Pierce, Rockford, IL; Santa Cruz Biotechnology, Santa Cruz, CA; Cell Signaling Technology, Beverly, MA; Cell Signaling Technology, Danvers, MA; Sigma-Aldrich, St. Louis, MO.

aa, amino acid; WB, Western blot; IHC, immunohistochemistry.

hours and 24 hours after the training trial), the mouse was again placed in the illuminated compartment and the latency to enter the dark compartment was recorded. The retention trial was interrupted if the animal took more than 180 seconds to cross into the dark compartment.

\section{Protein Extraction, Immunohistochemistry, and Western Blot}

Mice were sacrificed by $\mathrm{CO}_{2}$ asphyxiation, and their brains were cut in half sagittally. One half of the brain was fixed for 48 hours in $4 \%$ paraformaldehyde in phosphate-buffered saline for immunohistochemical analysis, whereas the other half was frozen in dry ice for biochemical analysis. Thick $(50 \mu \mathrm{m})$ free-floating sections were obtained using a vibratome slicing system. A detailed immunostaining procedure has been described previously. ${ }^{31,33}$ For purposes of immunohistochemistry, the primary antibodies were applied at the following dilutions: 1:1000 for 6E10, 1:5000 for AT100, and 1:1000 for the anti-A $\beta_{42}$ antibody D32. Antibodies were applied overnight at $4^{\circ} \mathrm{C}$. Sections were stained using the $\mathrm{DAB}$ chemistry (Vector Laboratories, Burlingame, CA).

Protein extracts were prepared by homogenizing whole brain hemisphere samples in T-per (Pierce) extraction buffer $(150 \mathrm{mg} / \mathrm{ml})$, complemented with a protease (Complete Mini Protease Inhibitor Tablets, Roche) and phosphatase inhibitors ( $5 \mathrm{mmol} / \mathrm{L}$ sodium fluoride and 1 $\mathrm{mmol} / \mathrm{L}$ sodium orthovanadate, Sigma), followed by centrifugation at $100,000 \times g$ for 1 hour. Protein concentra- tion in the supernatant was determined using the Bradford assay.

Equal amounts of protein $(20-50 \mu \mathrm{g}$, depending on protein of interest, specific for $A \beta^{\star} 56$ levels we loaded 50 $\mu \mathrm{g} / \mathrm{sample}$ in a 4 to $12 \%$ gradient gel and probed with 6 E10 antibody) were separated on 10 or 4 to $12 \%$ Bis/Tris gels (Invitrogen, Carlsbad, CA) and transferred to 0.45 $\mu \mathrm{mol} / \mathrm{L}$ polyvinylidene difluoride membranes. Membranes were blocked for 1 hour in $5 \%(\mathrm{v} / \mathrm{v})$ suspension of nonfat milk in $0.2 \%$ Tween 20 Tris-buffered saline $(\mathrm{pH}$ 7.5), and processed as described. Primary antibodies used for Western blots are summarized in Table 1. Quantitative densiometric analyses were performed using Image J 1.4 software.

\section{Enzyme-Linked Immunosorbent Assay (ELISA) for Soluble and Insoluble $A \beta$}

Soluble and insoluble $A \beta$ fractions were isolated from whole brain homogenates using T-per extraction buffer (Pierce) and $70 \%$ formic acid, respectively. Soluble fractions were loaded directly onto ELISA plates, whereas insoluble fractions were diluted 1:20 in a neutralization buffer $\left(1 \mathrm{~mol} / \mathrm{L}\right.$ Tris base, $0.5 \mathrm{~mol} / \mathrm{L} \mathrm{NaH}_{2} \mathrm{PO}_{4}$ ) before loading. MaxiSorp immunoplates (Nunc, Rochester, NY) were coated with mAB20.1 antibody (a kind gift from Dr. W. Van Nostrand, Stony Brook University, Stony Brook, $\mathrm{NY})$ at a concentration of $25 \mu \mathrm{g} / \mathrm{ml}$ in coating buffer $(0.1$ $\mathrm{mol} / \mathrm{L} \mathrm{Na}_{2} \mathrm{CO}_{3}, \mathrm{pH}$ 9.6) and blocked with $3 \%$ bovine serum albumin. Standard solutions for both $A \beta_{1-40}$ and 
Table 2. Study Design

\begin{tabular}{|c|c|c|c|c|c|c|c|c|}
\hline & \multirow{2}{*}{$\begin{array}{l}\text { Beginning of the } \\
\text { treatment } \\
\text { age (months) }\end{array}$} & \multirow{2}{*}{$\begin{array}{c}\text { End of the } \\
\text { treatment } \\
\text { age (months) }\end{array}$} & \multicolumn{4}{|c|}{ n/group } & \multirow[b]{2}{*}{ Dosage } & \multirow{2}{*}{$\begin{array}{c}\text { Plasma levels } \\
\text { of memantine } \\
\qquad(\mathrm{ng} / \mathrm{ml})\end{array}$} \\
\hline & & & $\begin{array}{l}\text { Non-Tg } \\
\text { vehicle }\end{array}$ & $\begin{array}{l}\text { Non-Tg } \\
\text { memantine }\end{array}$ & $\begin{array}{c}3 \times T g \\
\text { vehicle }\end{array}$ & $\begin{array}{c}3 \times T g \\
\text { memantine }\end{array}$ & & \\
\hline Mild & 6 & 9 & 10 & 10 & 10 & 10 & $30 \mathrm{mg} / \mathrm{kg} / \mathrm{day}$ & 249.27 \\
\hline Moderate & 9 & 12 & 10 & 10 & 10 & 10 & 30 mg/kg/day & 123.42 \\
\hline Severe & 15 & 18 & 10 & 10 & 10 & 10 & 30 mg/kg/day & 132.09 \\
\hline
\end{tabular}

$\mathrm{A} \beta_{1-42}$ were made in the antigen capture buffer $(20 \mathrm{mmol} / \mathrm{L}$ $\mathrm{NaH}_{2} \mathrm{PO}_{4}, 2 \mathrm{mmol} / \mathrm{L}$ EDTA, $0.4 \mathrm{M} \mathrm{NaCl}, 0.05 \%$ 3-[(3cholamidopropyl)dimethylammonio]propanesulfonate, and $1 \%$ bovine serum albumin, $\mathrm{pH} 7.0$ ) and loaded onto ELISA plates in duplicate. Samples were then loaded (also in duplicate) and incubated overnight at $4^{\circ} \mathrm{C}$. Plates were then washed and probed with either horseradish peroxidaseconjugated anti-A $\beta_{1-40}(\mathrm{C} 49)$ or anti-A $\beta_{1-42}$ (D32) overnight at $4^{\circ} \mathrm{C}$. The chromogen was $3,3^{\prime}, 5,5^{\prime}$-tetramethylbenzidine, and the reaction was stopped by $30 \%$ phosphoric acid. The plates were read at $450 \mathrm{~nm}$ using a plate reader (Molecular Dynamics, Sunnyvale, CA). The readings were then normalized to protein concentrations of the samples.

\section{LTP Experiments}

All experimental protocols were approved by the Ethical Committee on Animal Care and Use of the Government of Bavaria, Germany. The brains of 2-month-old BL6/C57 mice were rapidly removed, and transverse 350- $\mu \mathrm{m}$ slices were prepared in ice-cold Ringer solution, using a vibroslicer. The slices were placed in a holding chamber for at least 60 minutes and were then transferred to a perfusion chamber for extracellular recordings. Before use, the perfusion buffer (124 mmol/L NaCl, $3 \mathrm{mmol} / \mathrm{L} \mathrm{KCl}, 26 \mathrm{mmo} / \mathrm{L} \mathrm{NaHCO}_{3}, 2$ $\mathrm{mmol} / \mathrm{L} \mathrm{CaCl}, 1 \mathrm{mmol} / \mathrm{L} \mathrm{MgSO}_{4}, 10 \mathrm{mmol} / \mathrm{L}$ D-glucose, and $1.25 \mathrm{mmol} / \mathrm{L} \mathrm{NaH}_{2} \mathrm{PO}_{4}$ ) was bubbled with a $95 \%$ $\mathrm{O}_{2}-5 \% \mathrm{CO}_{2}$ mixture, and had a final $\mathrm{pH}$ of 7.3 . The flow rate of the solution through the chamber was $1.5 \mathrm{ml} / \mathrm{min}$. All measurements were performed at room temperature. The $42 \mathrm{nmol} / \mathrm{L} A \beta$ oligomeric preparation was based on the protocol by ${ }^{34}$ and was bath-applied for 90 minutes. In experiments with memantine, slices were stored in the perfusion buffer containing this compound $(1 \mu \mathrm{mol} / \mathrm{L})$ for at least 6 hours, which allowed the drug to achieve equilibrium blockade. $^{35}$

\section{Electrophysiologic Recording}

Field excitatory postsynaptic potentials (fEPSPS) in the hippocampal slices were evoked by delivering electric stimuli $(0.033 \mathrm{~Hz}, 4-5 \mathrm{~V}, 20 \mu \mathrm{s})$ to the Schaffer collateralcommissural pathway, and recorded in the dendritic region of the CA1 region using glass micropipettes (1-2 $\mathrm{M} \Omega$ ) filled with the perfusion solution. LTP was induced by a high-frequency, tetanic pulse $(100 \mathrm{~Hz} / 1$ second), applied to the Schaffer collateral-commissural pathway. Postinduction fEPSP slope measurements represented the $20-80 \%$ fragment of the peak amplitude. All fEPSP slopes were normalized against the 30-minute control period preceding the tetanic stimulation. The fEPSPS were amplified, filtered $(3 \mathrm{kHz})$, digitized $(15 \mathrm{kHz})$ and analyzed using the LTP Program software version 1.01, available at $h$ ttp://www.Itp-program.com ${ }^{36}$ (last accessed on June 18, 2008).

Statistical analysis, comparing all measurements to the 10-minute average of a stable baseline control, was performed using the Student's paired $t$-test with the significance level of $\alpha=0.01$. All values are presented as mean \pm SEM.

\section{Results}

To evaluate the effects of memantine in mice with different stages of AD-like pathology and cognitive deficits, we administered the drug to three age groups of animals for 3 months, after which the animals were tested on a battery of cognitive tasks, followed by an assessment of the neuropathology (Table 2). At the beginning of treatment, the mice were 6,9 , and 15 months of age, which corresponds to mild, moderate, and severe pathology of ADlike symptoms, respectively. ${ }^{10,13}$ The control animals were age- and sex-matched, cognitively normal nontransgenic (NonTg) mice. Throughout the study, no adverse changes in general health or significant weight changes in any treatment group were observed. The mean $( \pm S D)$ steady-state plasma concentration of memantine determined after behavioral testing was $157.9 \pm$ $22.4 \mathrm{ng} / \mathrm{ml}(0.88 \pm 0.13 \mu \mathrm{mol} / \mathrm{L})$, with relatively greater memantine levels in females $(262 \mathrm{ng} / \mathrm{ml})$ than in males $(111 \mathrm{ng} / \mathrm{ml})$.

\section{Memantine Ameliorates Cognitive Impairment}

The cognitive abilities of mice were evaluated using the Morris water maze, novel-object recognition task, and passive inhibitory avoidance. These tasks are mainly dependent on the hippocampus, cortex and amygdala, respectively, and were selected because $A \beta$ and tau accumulation first occurs and is most pronounced in those three regions. ${ }^{10,13}$

Before memantine treatment, the mice were first subjected to Morris water maze-based spatial memory training, followed by short-term (1.5 hours) and long-term (24 hours) memory probe trials, to determine their baseline performance (Figure 1). The learning ability of 3xTg-AD mice in all three age groups was significantly impaired, compared with age-matched control animals. After this initial assessment of cognition, mice were randomly assigned to either memantine or sucrose treatment for 3 


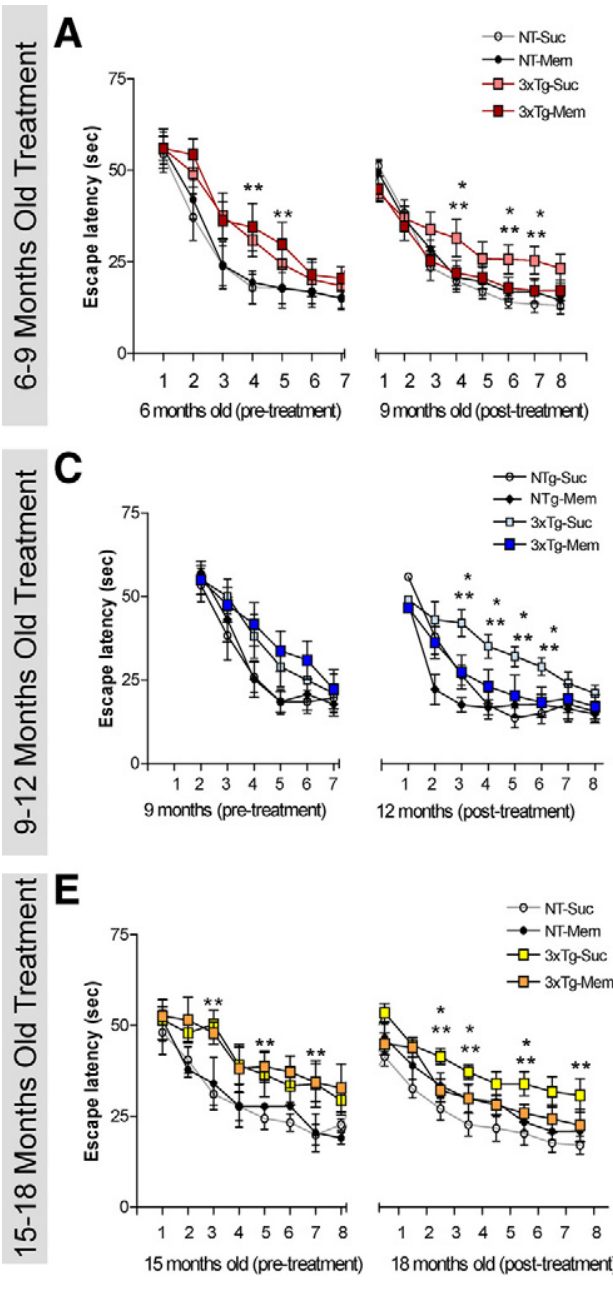

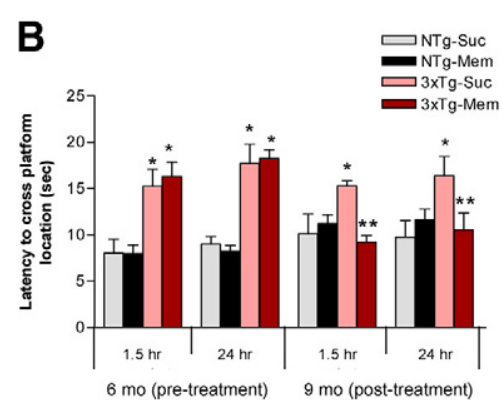
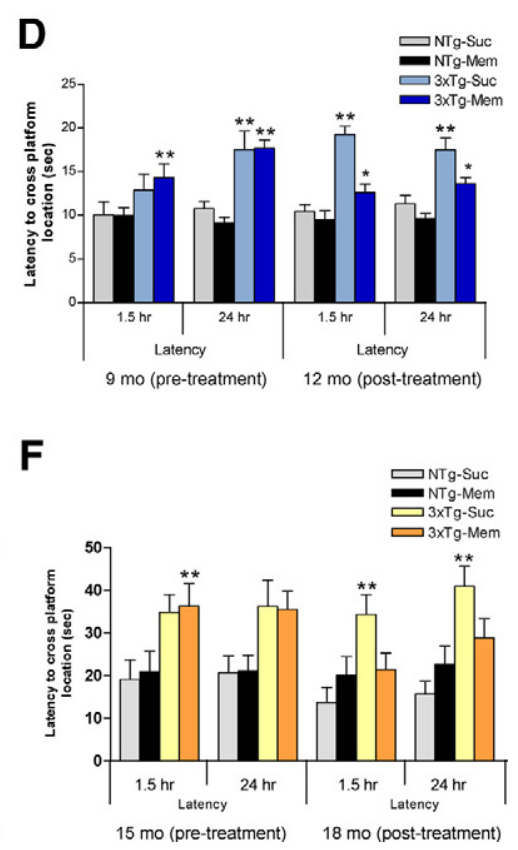

Figure 1. Memantine improves spatial cognitive deficits in 3xTg-AD mice. Memantine-treated 3xTg-AD mice were evaluated using a spatial reference paradigm and compared with sucrosetreated 3xTg-AD and NonTg mice. Mice were trained on the spatial reference version of the Morris water maze task before and after treatment. All three groups (6,9, and 12 months old) of memantine-treated 3xTg-AD mice showed impairment compared with NTg mice during the pretreatment training phase $(\mathbf{A}, \mathbf{C}$, and $\mathbf{E})$, which largely disappeared after 3 months of memantine treatment $(\mathbf{A}, \mathbf{C}$, and $\mathbf{E})$. Similarly, all 3xTg-AD mice showed both short (1.5 hours) and long-term ( 24 hours) memory deficits during the pretreatment retention trials $(\mathbf{B}, \mathbf{D}$, and $\mathbf{F})$, but the mice with mild and moderate pathology demonstrated a significant improvement after treatment (B and $\mathbf{D}$ ). ${ }^{* *} P<0.05$, memantine-treated $3 \times \mathrm{Tg}-\mathrm{AD}$ mice versus sucrosetreated NTg mice. ${ }^{*} P<0.05$, memantinetreated 3xTg-AD mice versus sucrose-treated 3xTg-AD mice. months without interruption. The training sessions and memory probe trials were then repeated.

In the youngest, mild pathology group (6-9 months), sucrose-treated NonTg mice reached criterion in 4 days, whereas sucrose-treated 3xTg-AD mice required 8 days, but were still able to learn the task (Figure 1A). Memantine-treated 3xTg-AD mice reached criterion after 4 days, thereby paralleling the performance of NonTg mice, whose performance was unaffected by memantine treatment (Figure 1A). Memantine treatment also rescued the learning deficits observed in the moderate pathology group (12 months old). The 12-month-old sucrosetreated NonTg mice reached criterion in 4 days, whereas the sucrose-treated $3 \times \mathrm{Tg}-\mathrm{AD}$ mice reached it in 8 days, and most notably, the memantine-treated mice reached criterion in 5 days (Figure 1C). Memantine improved acquisition performance in the severe pathology group as well (18 months old; Figure 1E), although the effect was not as pronounced as with the younger two groups. Sucrose-treated NonTg mice reached criterion in 7 days, whereas the sucrose-treated 3xTg-AD mice were not able to reach criterion even after 8 days of training. However, memantine-treated 3xTg-AD mice performed similarly to NonTg mice treated with memantine and were able to learn the task within 8 days.
To determine the effects of memantine on short- and long-term memory, probe trials were conducted 1.5 and 24 hours after the last training trial. Similar to the training sessions, all 3xTg-AD mice showed a significant cognitive impairment before the treatment. However, after 3 months of treatment, memantine significantly improved the performance of the 3xTg-AD mice, as demonstrated by the marked reduction in the latency of all age groups to cross the platform location (Figure 1, B, D, F). This improvement in performance was significant in mice with mild and moderate pathology, while mice with severe pathology showed a similar trend. Memantine had no effect on the performance of NonTg mice during either the training or probe trials.

After the Morris water maze test, the mice were subjected to a novel object recognition task, which is dependent on perirhinal and insular cortex..37,38 After habituation with the familiar object, mice were tested at both 1.5 and 24 hours later. All three groups of sucrose-treated 3xTg-AD mice performed significantly worse than NonTg mice, but memantine treatment significantly improved the performance of the mild pathology group (see Supplemental Figure S1, A-C, at http://ajp.amjpathol.org).

Finally, the mice were evaluated in a contextual learning and memory task (passive inhibitory avoidance), which is 

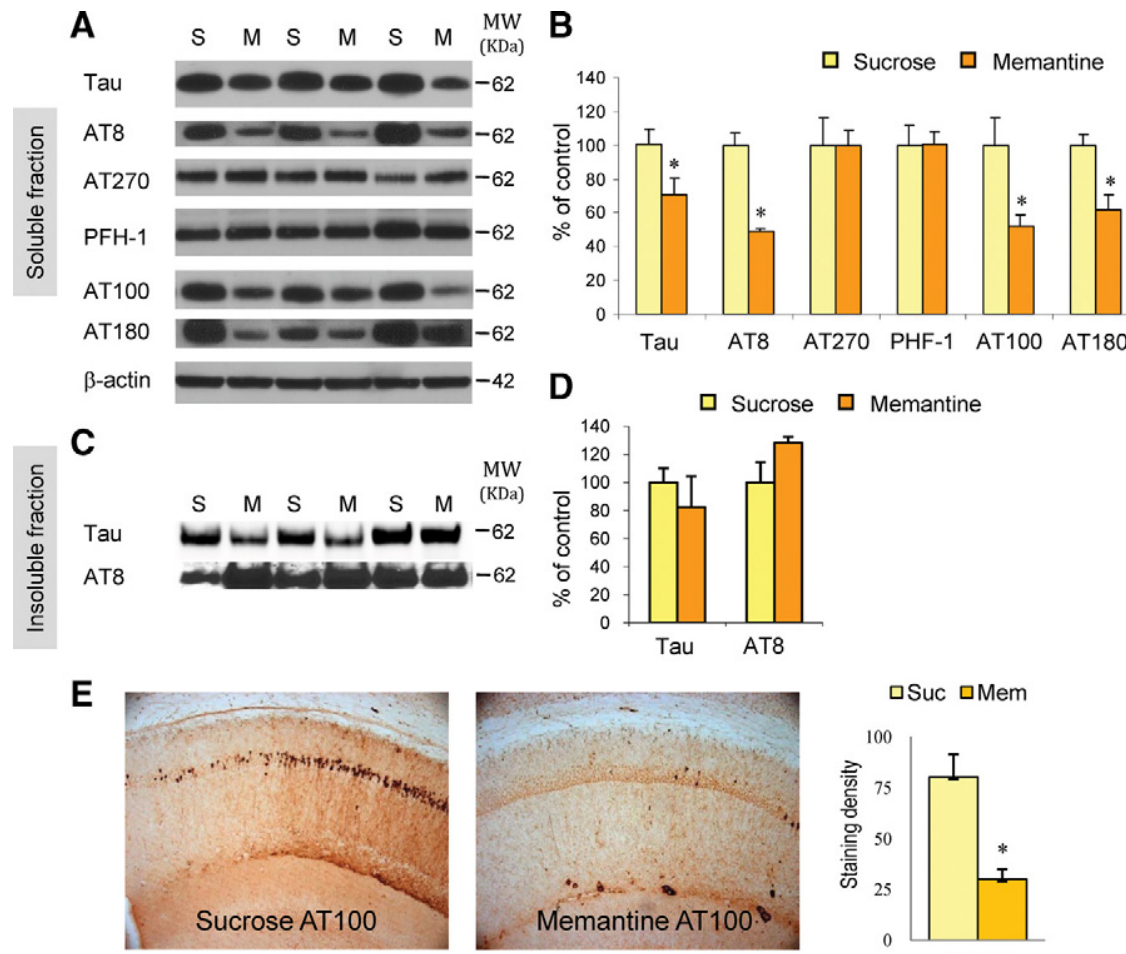

MW G
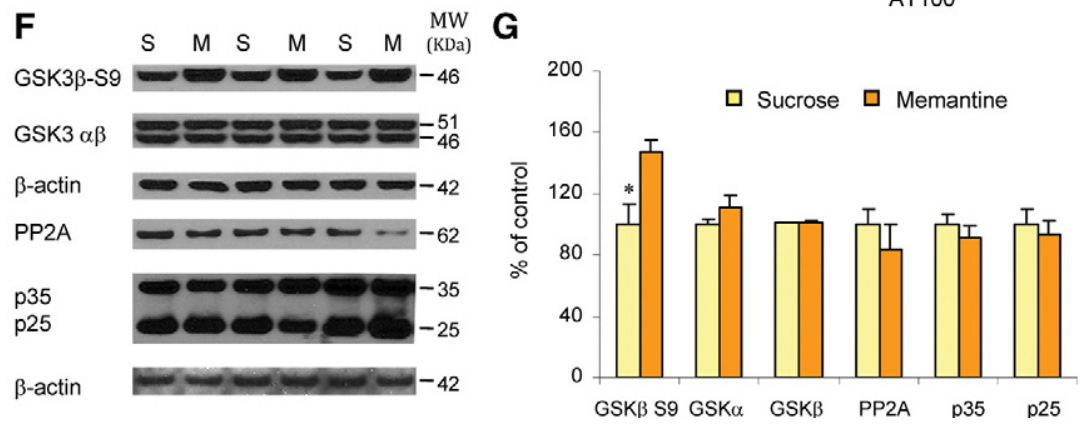

Figure 2. Memantine reduces accumulation and phosphorylation of tau in 3xTg-AD mice may be mediated by GSK3 3 . After 3 months of memantine treatment, total levels of the soluble fraction of tau protein in 3xTg-AD mice with severe pathology (A and $\mathbf{B}$ ) were significantly lower, compared with the sucrose-treated animals, using HT7 antibody. Memantine treatment was also associated with significantly lower levels of tau phosphorylated at residues 212/214 (AT100), 199/202 (AT8), 212/214 (AT100), and 231 (AT180) (A and B). Levels of total tau (HT7) and phosphorylated tau at 199/202 residues had no significantly changes (C and $\mathbf{D})$. Immunostaining using AT100 antibody revealed a significantly reduction in somatodendritic tau phosphorylated at residues $212 / 214(\mathbf{E})$. Western blot analysis shows that the levels of inactive GSK3 $\beta$ (phospho-GSK3 $\beta$-S9) were increased by memantine treatment in 3xTg-AD, compared with sucrose-treated mice (F and $\mathbf{G})$. Levels of p 25 and PP2A do not show differences with memantine treatment in mice with severe pathology (F and $\mathbf{G}) .{ }^{*} P<0.05$, memantine-treated $3 \times \mathrm{Tg}$-AD mice versus sucrose-treated $3 \times \mathrm{Tg}-\mathrm{AD}$ mice. $\mathrm{S}$, sucrose-treated; M, memantine-treated. primarily dependent on the amygdala. ${ }^{39}$ Sucrose-treated NonTg mice avoided the dark, shock-associated compartment, whereas the sucrose-treated 3xTg-AD mice in all three age groups showed a significantly impaired shortand long-term memory. Both were significantly improved by memantine treatment in the youngest group, whereas only long-term memory was improved in the moderate-pathology group and produced a similar trend in the more severely impaired mice (see Supplemental Figure S1, D-F, at http://ajp.amjpathol.org).

\section{Memantine Had No Effect on the NonTg Mice}

These data demonstrate that chronic memantine treatment can significantly alleviate cognitive deficits in a mouse model of $A D$ and across the entire range of $A D$ like pathology. Following behavioral testing, mice were sacrificed and their brains were harvested for biochemical and immunohistochemical analyses.

\section{Memantine Treatment Reduces \\ Somatodendritic Accumulation and Phosphorylation of Tau}

Tau pathology progresses in a hierarchical manner, beginning with somatodendritic accumulation, ${ }^{10}$ followed by changes in conformation and phosphorylation patterns, and eventually developing into mature neurofibrillary tangles. ${ }^{10}$ Figure 2 focuses on tau pathology in the severe pathology group of mice, while the effects of memantine on moderate groups are shown in Supplemental Figure S2, A and B, at http://ajp.amjpathol.org. In our study, memantine treatment was associated with a significant reduction in steady-state levels of tau protein in the mice groups with severe pathology, as detected by Western blotting with antibodies to tau using the soluble brain homogenate fraction (Figure 2, A and B). In addition, we found that the levels of tau phosphorylated on residues 212/214 (recognized by the AT100 antibody), residues 199/202 (AT8 antibody), and 231 (AT180 anti- 


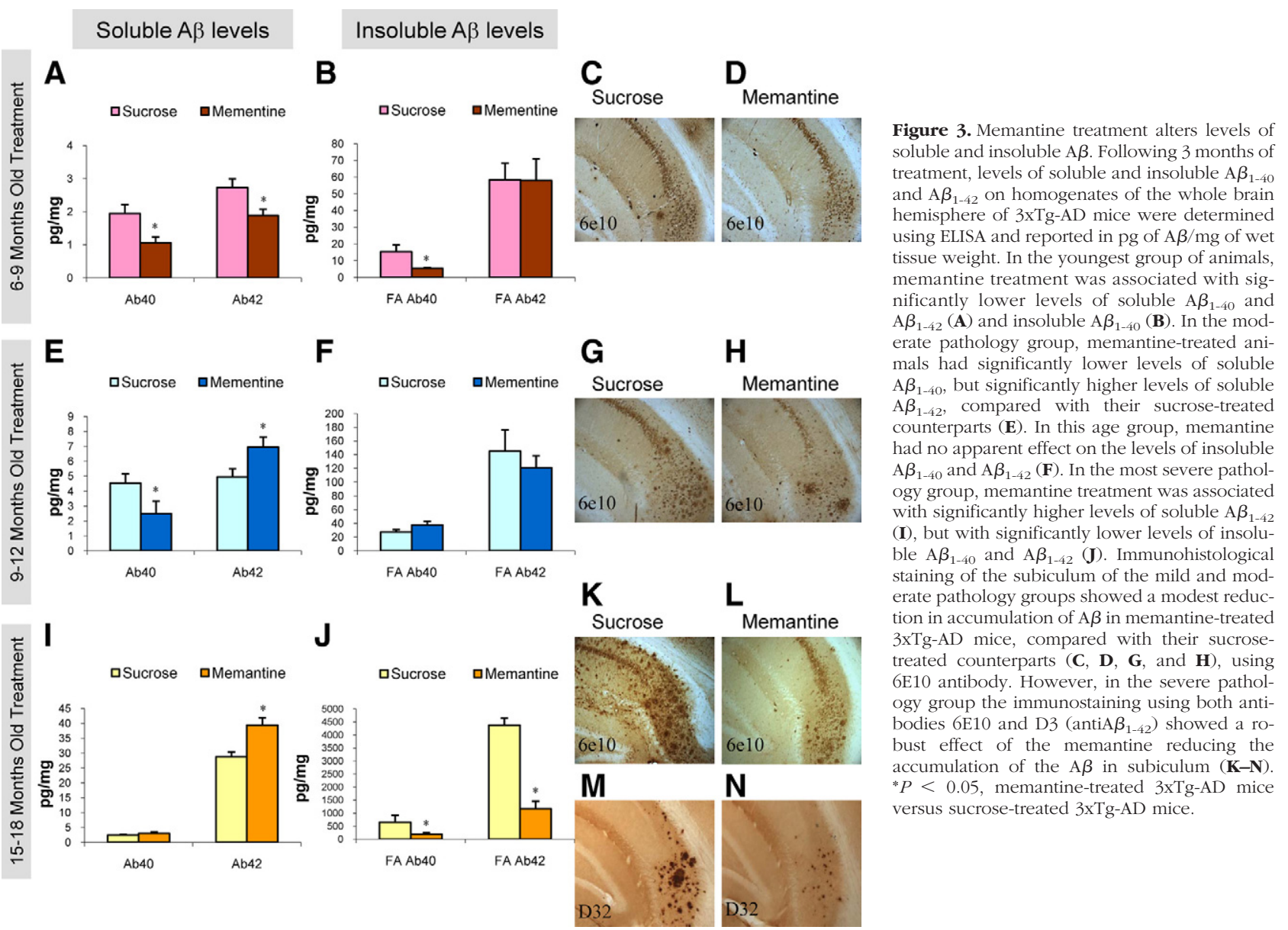

body) were reduced. The levels of phospho-tau species recognized by antibodies PHF1 and AT270 were unaffected by memantine treatment. Levels of total tau, and AT8 positive tau, in the insoluble fraction were unaffected by the treatment (Figure 2, C and D). An immunohistochemical analysis of hippocampal regions using the AT100 antibody revealed a marked reduction in somatodendritic phospho-tau staining (Figure 2E). We also assessed tau pathology in the moderate pathology group, and showed similar reductions in steady-state tau, and tau phosphorylated at residues 212/214 (AT100) and 231 (AT180) (see Supplemental Figure S2, A and B, at http://ajp.amjpathol.org).

Since all of the tau residues that showed decreased phosphorylation in the presence of memantine in the severe pathology group are known targets of glycogen synthase kinase $3 \beta$ (GSK3 $\beta$ ), we next examined the levels of this enzyme. After 3 months of memantine treatment, mice in the two older groups exhibited significantly higher levels of the inactive GSK3 $\beta$ form, compared with their sucrose-treated counterparts (Figure 2, F and G). This suggests a decrease in the levels of active GSK3 $\beta$ in memantine-treated animals, which could account for the observed reductions in the levels of GSK3 $\beta$-phosphorylated tau residues. We found a similar effect on the inactive form of GSK3 $\beta$ in the moderate pathology group (see Supplemental Figure S2, C and D, at http://ajp.amjpathol.org). Finally, the levels of two other me- diators of tau phosphorylation, p25 (the co-activator for cyclin-dependent kinase 5, another tau kinase), ${ }^{40}$ and PP2a, a tau phosphatase, were unaffected by memantine treatment (Figure 2, F and G).

\section{Memantine Treatment Reduces A $\beta$ Accumulation}

Transgenic 3xTg-AD mice increasingly accumulate $A \beta$ as they age, with fibrillar amyloid plaques starting to develop from 12 months of age.$^{31}$ Our earlier data indicate that the initial cognitive deficits in these mice are caused by intraneuronal $A \beta$ levels ${ }^{11}$ and that cognitive deficits increase with increasing brain pathology. To determine the effects of chronic memantine treatment on the $A \beta$ load, we assessed whole brain hemisphere $A \beta$ levels using sandwich ELISA.

Memantine treatment significantly reduced levels of soluble $A \beta_{1-42}$ in the mild pathology group of mice, while soluble $A \beta_{1-42}$ was increased in animals with moderate and severe pathology (Figure 3, A, E, I). Notably, these effects are concomitant with a large reduction of insoluble $A \beta_{1-42}$ levels in the severe pathology group of animals, which may represent an effect of memantine treatment on distribution of the $A \beta$, causing a shift from the insoluble $A \beta 42$ to soluble pool of $A \beta$ (Figure 3 , I and J). In mice with mild and moderate pathology memantine had 
no effect in the insoluble fraction, possibly due to fewer dense core plaques in younger mice (Figure $3, \mathrm{~B}$ and F), despite rescuing cognitive deficits in these mice. Memantine treatment also significantly reduced levels of soluble $A \beta_{1-40}$ in animals with mild and moderate pathology (Figure $3, A$ and $E$ ). In the group with severe pathology the treatment had no effect in soluble $A \beta_{1-40}$ and significantly reduction in insoluble $A \beta_{1-40}$ (Figure $3, I$ and $\mathrm{J}$ ).

Immunohistochemical staining revealed a stark contrast in $A \beta$ levels between the sucrose- and memantinetreated $3 \times T g-A D$ mice in the severe pathology group, showing a considerable reduction in the number of plaques as a consequence of memantine treatment (Figure $3, C, D, G, H, K-N)$. These results indicate that the effect of memantine on the levels of $A \beta$ may be related to alterations in the distribution of $A \beta$ pools and is dependent on age or severity of pre-existing $A \beta$ pathology (see Supplemental Figure S3, A-D, at http://ajp.amjpathol.org).

\section{Memantine Reduces Levels of A Oligomers}

$A \beta$ levels can be affected by a variety of proteins involved in $A \beta$ production and degradation. Therefore, we attempted to evaluate whether the processing of amyloid precursor protein (APP) could account for the marked decrease in $A \beta$ levels observed after memantine treatment in the mice with severe pathology. Our measurements indicate that the steady-state levels of full-length APP were unaltered with memantine treatment (Figure 4, $A$ and $B$ ), although we cannot discount the possibility that APP levels could be C-terminally truncated as 6E10 would be unable to distinguish slight shifts in molecular weight due to caspase cleavage. Western blot analysis of homogenates using 6E10 antibody also revealed that, in the severe group of mice, memantine treatment decreased the concentration of $A \beta$ dodecamer, $A \beta^{\star} 56$, by approximately $70 \%$ (Figure $4, \mathrm{~A}$ and $\mathrm{B}$ ). We next measured the levels concentration of C83 and C99, C-terminal APP fragments that are byproducts of $\alpha$ - and $\beta$-secretase, respectively, but could not detect any memantine-dependent effects (Figure 4, A and B), nor could we resolve any smaller C-terminal fragments such as AICD or C31. Levels of $\alpha$-secretase, $\gamma$-secretase, insulin-degrading enzyme, and transthyretin (all involved in APP processing or downstream amyloid cascade) were also unchanged between the sucrose- and memantine-treated animals (Figure 4, E and F).

Given the intriguing decline in $A \beta^{\star} 56$ levels, we assessed total prefibrillar and fibrillar $A \beta$ oligomeric levels using $\mathrm{A} 11$ and $\mathrm{OC}$ antibodies, respectively, in the soluble fraction. ${ }^{41}$ The antibody $A 11$ recognizes $A \beta$ oligomers with a molecular mass of $50-150 \mathrm{kd}$, including $A \beta^{\star} 56$. Memantine treatment was associated with approximately a $30 \%$ decrease in levels of the prefibrillar oligomers in the soluble fraction (antibody A11); however, the levels of fibrillar oligomers were decreased in female mice only (Figure 4, C and D). These data suggest that memantine treatment affects $A \beta$ oligomerization, and that its effects may be dependent on the severity of $A \beta$ pathology, and
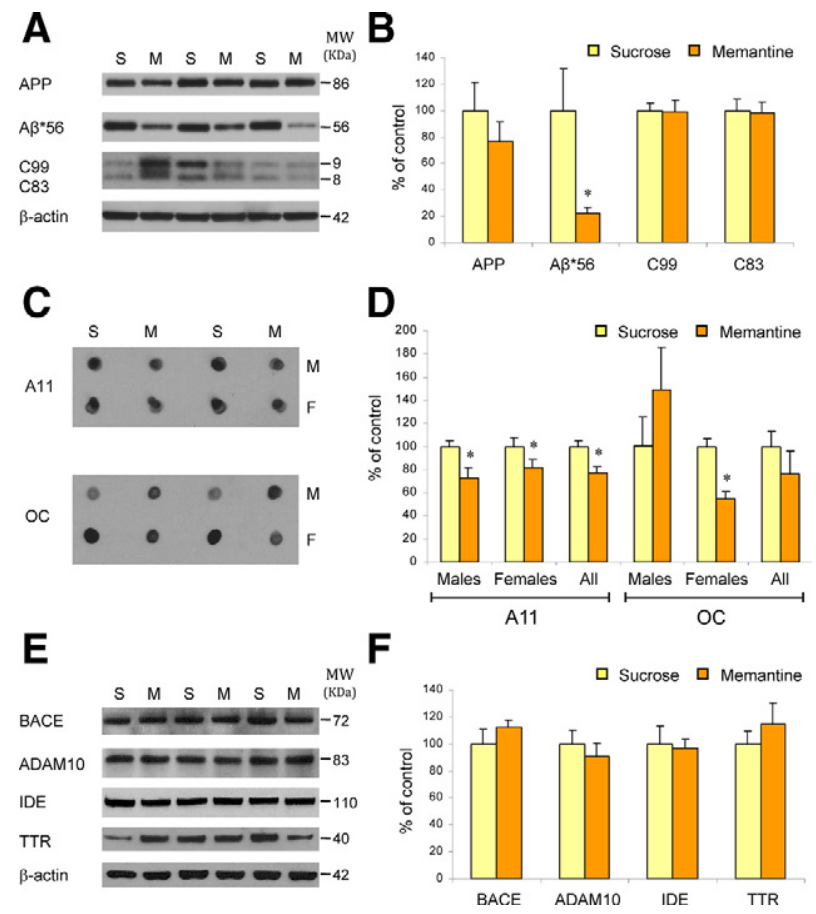

Figure 4. Memantine reduces oligomer formation in the $3 \mathrm{xTg}-\mathrm{AD}$ mice. Western blot analysis of homogenates of whole brain hemisphere revealed no difference in the levels of APP, C99 fragment, C83 fragment, ADAM10, and BACE between the memantine- and sucrose-treated 3xTg-AD mice, using 6E10, CTF20, anti-ADAM10, anti- $\beta$-site APP cleaving enzyme (BACE) antibodies respectively, $(\mathbf{A}, \mathbf{B}, \mathbf{E}, \mathbf{F})$. However, the levels of the $\mathrm{A} \beta$ dodecamer (A $\beta^{* 56}$ ) (using 6E10 antibody) were significantly lower in memantine-treated animals (A and $\mathbf{B}$ ). In addition, dot blot analysis indicated a significan reduction in the levels of all prefibrillar oligomers (A11 antibody) in memantine-treated mice (male and female), and lower levels of fibrillar oligomers (OC antibody) in female animals only $(\mathbf{C}$ and $\mathbf{D}) .{ }^{*} P<0.05$, memantinetreated 3xTg-AD mice versus sucrose-treated 3xTg-AD mice.

sex. Notably, no changes in $A \beta^{*} 56$ were seen in the moderate pathology group, despite robust improvements in behavior.

\section{Memantine Reverses Oligomeric A $\beta$-Induced Deficits in LTP}

To investigate the possibility that oligomeric $A \beta$ affects neuronal excitability in the CA1 region of the hippocampus, evoked potentials and LTP were measured in murine hippocampal slices incubated with an oligomeric $A \beta$ induced preparation. Under control conditions, 60 minutes after high-frequency stimulation, fEPSP slopes were potentiated to $139.7 \pm 6.3 \%$ of baseline $(n=10)$. However, after 90 minutes of pretreatment with oligomeric $\mathrm{A} \beta$-induced (42 $\mathrm{nmol} / \mathrm{L})$, the same stimulus produced only a short-term potentiation, after which the fEPSP slope reversed to $102.2 \pm 2.9 \%$ of baseline $(n=10 ; P<$ 0.01 ; Figure 5). The pretreatment with oligomeric $A \beta$ induced had no effect on the baseline fEPSP slope (data not shown). Pretreatment with memantine $(1 \mu \mathrm{mol} / \mathrm{L}) \mathrm{did}$ not affect the magnitude of LTP $(131.9 \pm 4.7 \% ; n=10)$, but was able to prevent the oligomeric A $\beta$-induced LTP impairment effect almost completely $(128.5 \pm 5.8 \% ; n=$ 10; $P<0.05$; Figure 5). Taken together, these data indicate that memantine treatment can alleviate cognitive 

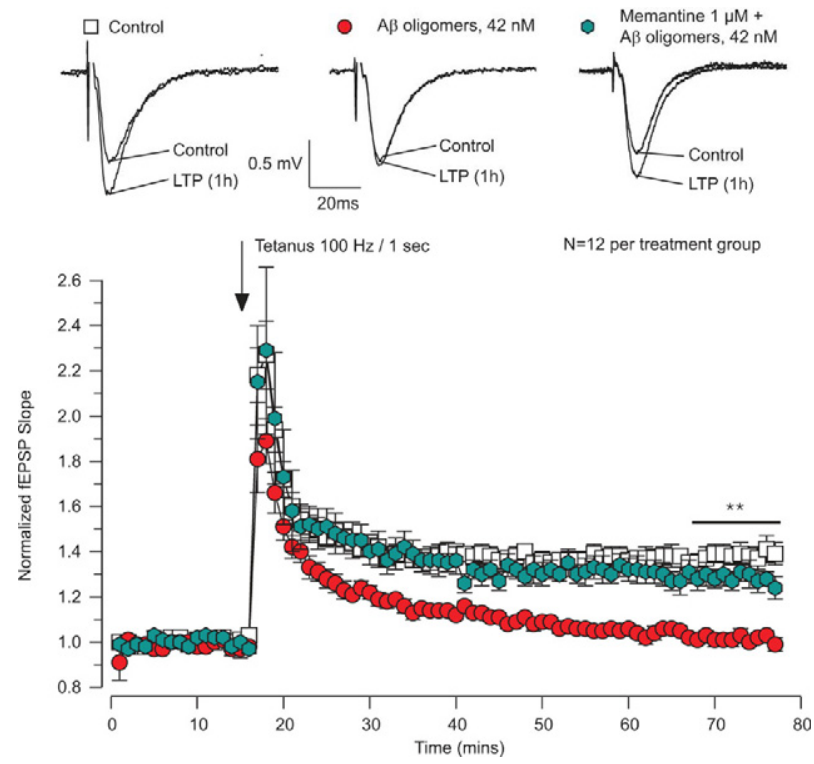

Figure 5. Memantine prevents A $\beta$ oligomer induced inhibition of LTP. Application of $\mathrm{A} \beta(42 \mathrm{nmol} / \mathrm{L})$ for 90 minutes blocked LTP in slices of hippocampal CA1. Induction of LTP (arrow) and maintenance for 1 hour. Representative traces of single experiments are shown before (control) and 1 hour after tetanization ( $100 \mathrm{~Hz} / 1$ second). Memantine restored LTP in the presence of $\mathrm{A} \beta$. There was no difference in the fEPSP potentiation after 1 hour of LTP induction when slice were incubated for at least 6 hours with memantine $(1 \mu \mathrm{mol} / \mathrm{L})$ under control conditions (not shown) and after wash-in of $\mathrm{A} \beta$. Representative traces of single experiments are shown before (control) and 1 hour after HFS. Data represent the summary of recordings from slices of 10 animals.

deficits in a transgenic mouse model of $A D$ at various stages of AD-like pathology and that it may have diseasemodifying effects.

\section{Discussion}

The NMDA receptor, one of three major types of ionotropic glutamate receptors, plays an important role in calcium homeostasis, synaptic plasticity, and learning and memory. Its function is tightly regulated, and if perturbed, can result in glutamate-triggered excitotoxicity and neuronal death. ${ }^{42}$ Similarly, complete inhibition of this receptor also results in impairment of synaptic plasticity and memory. ${ }^{43}$ Dysregulation of NMDA receptors have been implicated in $A D$, and it has been reported that the NMDA receptor-expressing neurons are more vulnerable to AD-associated insults. ${ }^{44,45}$ Memantine, an uncompetitive, voltage-dependent, moderate-affinity NMDA receptor antagonist, has been shown to slow clinical decline in patients with moderate to severe AD. ${ }^{46-48}$ The pharmacological action of memantine in $A D$ is thought to be based on its ability to reduce overactivation of NMDA receptors, while allowing normal activity to occur. However, some studies have investigated the disease-modifying effects of memantine in animal models of AD. ${ }^{49}$ In this study, we found that memantine improved both hippocampus- and amygdala-dependent memory impairments in 3xTg-AD mice of three different ages and degrees of pathology.
Both overactivation and inhibition of NMDA receptors have been reported to cause LTP deficits. ${ }^{8}$ It has been speculated that partial inhibition by memantine restores the physiological functioning of NMDA receptors, and thus LTP, ${ }^{35}$ which in turn leads to an improvement of cognitive function. Here we show that, in line with previous findings, low concentrations of bath-applied $A \beta$ oligomers inhibit LTP, ${ }^{50-52}$ an effect that can be abolished by preincubation with memantine. This long preincubation period is necessary, since memantine, an amphiphilic compound, exhibits slow penetration into the slice culture layers. These results suggest two things: first, that $A \beta$ oligomer-induced synaptic deficits occur via the NMDA receptor; and second, that memantine can protect against $A \beta$ oligomer-induced synaptic dysfunction. As synaptic dysfunction is widespread in $A D$ transgenic mouse models and occurs at ages that also show cognitive impairment, this memantine-induced prevention of synaptic deficits may be related to the improvements in cognition seen with treatment.

Several studies of memantine in transgenic mouse models of $A D$ have been performed by different laboratories. ${ }^{23-25,49}$ In these studies, functional outcomes have been extensively investigated and described, without fully examining the effects of memantine treatment on both tau and $A \beta$ pathology. Our present study shows findings from both behavioral and pathological perspectives and suggests that memantine may be a diseasemodifying drug for AD. A study of subchronic (10 days), subcutaneous treatment of aged Tg2576 mice demonstrated that the use of memantine was associated with reduced levels of membrane-bound APP, suggesting that longer treatment may reduce overall $A \beta$ production. ${ }^{53}$ In our experiments, memantine treatment (oral, 90 days) lead to significantly decreased levels of insoluble $A \beta$ in mice with severe pathology. However, the levels of full-length APP and of the C99 and C83 fragments were unchanged by memantine treatment, indicating that memantine does not modulate APP processing in these animals. It should be noted that we did not assess the kinetics of APP processing in memantine-treated mice, and therefore it is possible that our analyses of steadystate levels of APP fragments and secretases may miss more subtle effects of memantine treatment on APP processing. However, it is unlikely that any such subtle effects could underlie the robust reduction in the levels of insoluble $A \beta$ and the plaque load (approximately $70 \%$ for $\mathrm{A} \beta_{1-42}$ in memantine-treated mice). Rather, memantine may directly or indirectly affect the clearance or assembly/disassembly of $A \beta$ species in the brain. Although the mechanism remains unknown, it may include prevention of $A \beta$ monomer aggregation into oligomeric forms and, subsequently, into $A \beta$ plaques. This possibility is supported by our observation that memantine treatment in the most severely affected mice led to significantly increased soluble $A \beta_{1-42}$ levels but significantly reduced the levels of insoluble $A \beta$ and hippocampal amyloid deposition. Interestingly, the levels of $A \beta^{\star} 56$, an $A \beta$ oligomer, were markedly reduced in memantine-treated mice in the severe pathology group, as were the total oligomer levels, which include the $A \beta^{\star} 56$ fraction as part of the overall 
oligomer pool. However, the levels of fibrillar oligomers were lowered in memantine-treated females only, and there was no difference in cognitive performance between the two sexes. This effect could be due to relatively greater plasma memantine levels in females $(262 \mathrm{ng} / \mathrm{ml})$ than in males $(111 \mathrm{ng} / \mathrm{ml})$ found in this study. Notably, no changes in $A \beta^{\star} 56$ were seen in the moderate pathology group, despite robust improvements in behavior. Hence cognitive recovery occurs in the moderate group without such a reduction in this oligomeric species, or large changes in overall $A \beta$ levels, and suggests that cognitive improvement occurs due to the changes in tau pathology, or due to protection from the presence of $A \beta / A \beta$ oligomers, or a mixture of both.

Interestingly, memantine treatment also was associated with reduced steady-state levels of total tau, suggesting that tau has a greater turnover with memantine treatment, as production is under the control of the thy 1.2 promoter. This effect may be related to the lower levels of $A \beta$ oligomers, found in memantine-treated animals: we have previously shown that these oligomers impair neuronal proteasome activity and lead to increased levels of tau. ${ }^{54}$ In addition, we also found a significant reduction in the levels of tau phosphorylated at residues that are known targets for GSK3 $\beta$, a major tau kinase. ${ }^{55}$ It has been shown that the dysfunction of GSK3 $\beta$ impairs cognitive function, increases neuronal apoptosis, and alters pathological tau phosphorylation in various mouse models. ${ }^{56}$ In the 3xTg-AD mice, we previously observed an age-dependent activation of GSK3 $\beta$, which correlated with an increase in neuronal tau phosphorylation in the brain. ${ }^{57}$ In the present study, memantine treatment markedly increased the inhibitory phosphorylation of GSK3 $\beta$ at the Ser-9 residue, whereas the total levels of GSK $(3 \alpha+\beta)$ remained unchanged. This putative effect of memantine on GSK3 $\beta$ may be mediated via $A \beta$ oligomers, since it has been shown that lower levels of $A \beta$ oligomers lead to a lower activity of GSK3 $\beta .^{58}$ We found no differences in the levels of tau phosphorylated at other residues, nor changes in the levels of another major tau kinase, cdk5, or tau phosphatase, PP2a. This was surprising, considering that the overall tau levels in memantine-treated animals were significantly lower, compared with the sucrose-treated control group, and a comparable reduction in all phospho-tau molecules would have been expected. Finally, despite the lack of change between PHF1 and AT270, we think it unlikely that memantine treatment would stimulate the phosphorylation of tau at these residues. Tau phosphorylated at the PHF1/ AT270 sites may be more resistant to degradation by the proteasome compared with the molecule than is not phosphorylated or phosphorylated at other epitopes.

In conclusion, chronic memantine treatment of the 3xTg-AD mice not only improves the animals' cognitive performance, but also lowers the levels of pathological hallmarks of $A D, A \beta$ plaques and tau, in the 3xTg-AD mouse model. Although further studies would be required to reveal the molecular and cellular mechanisms of these results, our findings serve as important preclinical evidence for memantine as a disease-modifying drug for AD. Currently, memantine is approved only for the treat- ment of patients with moderate to severe $A D$, as studies of memantine in mild to moderate AD have not consistently revealed significant benefits in this patient population. ${ }^{7}$

\section{Acknowledgments}

We thank Drs. Charles Glabe and Suhail Rasool for antibodies A11 and OC11, David Cribbs and Vitaly Vasilevko for antibodies D32 and C49, Ms. Tatiania Estrada for assistance with mouse genotyping, and Mr. Alex Park for technical assistance. Drs. Vojislav Pejović and Michael L. Miller from Prescott Medical Communications Group provided editorial assistance.

\section{References}

1. Alzheimer's Association: Alzheimer's Disease Facts and Figures 2007. Chicago, Alzheimer's Association, 2007

2. Hui JS, Wilson RS, Bennett DA, Bienias JL, Gilley DW, Evans DA: Rate of cognitive decline and mortality in Alzheimer's disease. Neurology 2003, 61:1356-1361

3. Honig LS, Mayeux R: Natural history of Alzheimer's disease. Aging (Milano) 2001, 13:171-182

4. Selkoe DJ: Alzheimer's disease: genes, proteins, and therapy. Physio Rev 2001, 81:741-766

5. Selkoe DJ: Alzheimer's disease results from the cerebral accumulation and cytotoxicity of amyloid beta-protein. J Alzheimers Dis 2001, 3:75-80

6. Birks J: Cholinesterase inhibitors for Alzheimer's disease. Cochrane Database Syst Rev 2006 (1):CD005593

7. McShane R, Areosa Sastre A, Minakaran N: Memantine for dementia Cochrane Database Syst Rev 2006 (2):CD003154

8. Parsons CG, Stoffler A, Danysz W: Memantine: a NMDA receptor antagonist that improves memory by restoration of homeostasis in the glutamatergic system - too little activation is bad, too much is even worse. Neuropharmacology 2007, 53:699-723

9. Chen HS, Lipton SA: The chemical biology of clinically tolerated NMDA receptor antagonists. J Neurochem 2006, 97:1611-1626

10. Oddo S, Caccamo A, Kitazawa M, Tseng BP, LaFerla FM: Amyloid deposition precedes tangle formation in a triple transgenic model of Alzheimer's disease. Neurobiol Aging 2003, 24:1063-1070

11. Billings LM, Oddo S, Green KN, McGaugh JL, LaFerla FM: Intraneuronal Abeta causes the onset of early Alzheimer's disease-related cognitive deficits in transgenic mice. Neuron 2005, 45:675-688

12. Bliss TV, Collingridge GL: A synaptic model of memory: long-term potentiation in the hippocampus. Nature 1993, 361:31-39

13. Oddo S, Caccamo A, Shepherd JD, Murphy MP, Golde TE, Kayed R, Metherate R, Mattson MP, Akbari Y, LaFerla FM: Triple-transgenic model of Alzheimer's disease with plaques and tangles: intracellular Abeta and synaptic dysfunction. Neuron 2003, 39:409-421

14. Ascher $P$, and Johnson PW: The NMDA receptor, its channel, and its modulation by glycine. The NMDA receptor. Edited by G. L. Collingridge aJCW. New York, Oxford University Press, 1994, pp 177-205

15. Bi X, Gall CM, Zhou J, Lynch G: Uptake and pathogenic effects of amyloid beta peptide 1-42 are enhanced by integrin antagonists and blocked by NMDA receptor antagonists. Neuroscience 2002, 112:827-840

16. De Felice FG, Velasco PT, Lambert MP, Viola K, Fernandez SJ, Ferreira ST, Klein WL: Abeta oligomers induce neuronal oxidative stress through an N-methyl-D-aspartate receptor-dependent mechanism that is blocked by the Alzheimer drug memantine. J Biol Chem 2007, 282:11590-11601

17. Shankar GM, Bloodgood BL, Townsend M, Walsh DM, Selkoe DJ, Sabatini BL: Natural oligomers of the Alzheimer amyloid-beta protein induce reversible synapse loss by modulating an NMDA-type glutamate receptor-dependent signaling pathway. J Neurosci 2007, 27:2866-2875

18. Snyder EM, Nong Y, Almeida CG, Paul S, Moran T, Choi EY, Nairn AC, Salter MW, Lombroso PJ, Gouras GK, Greengard P: Regulation of 
NMDA receptor trafficking by amyloid-beta. Nat Neurosci 2005, 8:1051-1058

19. Couratier P, Lesort M, Sindou P, Esclaire F, Yardin C, Hugon J: Modifications of neuronal phosphorylated tau immunoreactivity induced by NMDA toxicity. Mol Chem Neuropathol 1996, 27:259-273

20. Danysz W, Parsons CG: The NMDA receptor antagonist memantine as a symptomatological and neuroprotective treatment for Alzheimer's disease: preclinical evidence. Int J Geriatr Psychiatry 2003, 18:S23-S32

21. Bakchine S, Loft H: Memantine treatment in patients with mild to moderate Alzheimer's disease: results of a randomised, double-blind, placebo-controlled 6-month study. J Alzheimers Dis 2007, 11:471-479

22. Wenk GL, Parsons CG, Danysz W: Potential role of N-methyl-Daspartate receptors as executors of neurodegeneration resulting from diverse insults: focus on memantine. Behav Pharmacol 2006, 17:411-424

23. Minkeviciene R, Banerjee $P$, Tanila $H$ : Memantine improves spatial learning in a transgenic mouse model of Alzheimer's disease. J Pharmacol Exp Ther 2004, 311:677-682

24. Van Dam D, Abramowski D, Staufenbiel M, De Deyn PP: Symptomatic effect of donepezil, rivastigmine, galantamine and memantine on cognitive deficits in the APP23 model. Psychopharmacology (Berl) 2005, 180:177-190

25. Van Dam D, De Deyn PP: Cognitive evaluation of disease-modifying efficacy of galantamine and memantine in the APP23 model. Eur Neuropsychopharmacol 2006, 16:59-69

26. Minkeviciene R, Banerjee P, Tanila H: Cognition-enhancing and anxioIytic effects of memantine. Neuropharmacology 2008, 54:1079-1085

27. Periclou A, Ventura D, Rao N, Abramowitz W: Pharmacokinetic study of memantine in healthy and renally impaired subjects. Clin Pharmacol Ther 2006, 79:134-143

28. Kornhuber J, Quack G: Cerebrospinal fluid and serum concentrations of the N-methyl-D-aspartate (NMDA) receptor antagonist memantine in man. Neurosci Lett 1995, 195:137-139

29. Frankiewicz T, Potier B, Bashir ZI, Collingridge GL, Parsons CG: Effects of memantine and MK-801 on NMDA-induced currents in cultured neurones and on synaptic transmission and LTP in area CA1 of rat hippocampal slices. Br J Pharmacol 1996, 117:689-697

30. Rammes G, Zieglgansberger W, Parsons CG: The fraction of activated $\mathrm{N}$-methyl-D-aspartate receptors during synaptic transmission remains constant in the presence of the glutamate release inhibitor riluzole. J Neural Transm 2008, 115:1119-1126

31. Oddo S, Caccamo A, Tran L, Lambert MP, Glabe CG, Klein WL, LaFerla FM: Temporal profile of amyloid-beta (Abeta) oligomerization in an in vivo model of Alzheimer disease: a link between Abeta and tau pathology J Biol Chem 2006, 281:1599-1604

32. Ennaceur A, Delacour J: A new one-trial test for neurobiological studies of memory in rats: 1. Behavioral data. Behav Brain Res 1988, 31:47-59

33. Oddo S, Caccamo A, Green KN, Liang K, Tran L, Chen Y, Leslie FM, LaFerla FM: Chronic nicotine administration exacerbates tau pathology in a transgenic model of Alzheimer's disease. Proc Natl Acad Sci USA 2005, 102:3046-3051

34. Barghorn S, Nimmrich V, Striebinger A, Krantz C, Keller P, Janson B, Bahr M, Schmidt M, Bitner RS, Harlan J, Barlow E, Ebert U, Hillen H: Globular amyloid beta-peptide oligomer-a homogenous and stable neuropathological protein in Alzheimer's disease. J Neurochem 2005, 95:834-847

35. Frankiewicz T, Parsons CG: Memantine restores long term potentiation impaired by tonic N-methyl-D-aspartate (NMDA) receptor activation following reduction of $\mathrm{Mg} 2+$ in hippocampal slices. Neuropharmacology 1999, 38:1253-1259

36. Anderson WW, Collingridge GL: The LTP Program: a data acquisition program for on-line analysis of long-term potentiation and other synaptic events. J Neurosci Methods 2001, 108:71-83

37. Barker GR, Bird F, Alexander V, Warburton EC: Recognition memory for objects, place, and temporal order: a disconnection analysis of the role of the medial prefrontal cortex and perirhinal cortex. J Neurosci 2007, 27:2948-2957

38. Bermudez-Rattoni F, Okuda S, Roozendaal B, McGaugh JL: Insular cortex is involved in consolidation of object recognition memory. Learn Mem 2005, 12:447-449

39. McGaugh JL, McIntyre CK, Power AE: Amygdala modulation of memory consolidation: interaction with other brain systems. Neurobiol Learn Mem 2002, 78:539-552
40. Kesavapany S, Zheng YL, Amin N, Pant HC: Peptides derived from Cdk5 activator p35, specifically inhibit deregulated activity of Cdk5. Biotechnol J 2007, 2:978-987

41. Kayed R, Head E, Sarsoza F, Saing T, Cotman CW, Necula M, Margol L, Wu J, Breydo L, Thompson JL, Rasool S, Gurlo T, Butler P, Glabe CG: Fibril specific, conformation dependent antibodies recognize a generic epitope common to amyloid fibrils and fibrillar oligomers that is absent in prefibrillar oligomers. Mol Neurodegener 2007, 2:18

42. Michaels RL, Rothman SM: Glutamate neurotoxicity in vitro: antagonist pharmacology and intracellular calcium concentrations. J Neurosci 1990, 10:283-292

43. Morris RG, Anderson E, Lynch GS, Baudry M: Selective impairment of learning and blockade of long-term potentiation by an N-methyl-Daspartate receptor antagonist. AP5 Nature 1986, 319:774-776

44. Francis PT, Webster MT, Chessell IP, Holmes C, Stratmann GC, Procter AW, Cross AJ, Green AR, Bowen DM: Neurotransmitters and second messengers in aging and Alzheimer's disease. Ann NY Acad Sci 1993, 695:19-26

45. Greenamyre JT, Young AB: Excitatory amino acids and Alzheimer's disease. Neurobiol Aging 1989, 10:593-602

46. Gauthier S, Wirth Y, Mobius HJ: Effects of memantine on behavioural symptoms in Alzheimer's disease patients: an analysis of the Neuropsychiatric Inventory (NPI) data of two randomised, controlled studies. Int J Geriatr Psychiatry 2005, 20:459-464

47. Tariot PN, Farlow MR, Grossberg GT, Graham SM, McDonald S Gergel I: Memantine treatment in patients with moderate to severe Alzheimer disease already receiving donepezil: a randomized controlled trial. JAMA 2004, 291:317-324

48. Reisberg B, Doody R, Stoffler A, Schmitt F, Ferris S, Mobius HJ: A 24-week open-label extension study of memantine in moderate to severe Alzheimer disease. Arch Neurol 2006, 63:49-54

49. Scholtzova H, Wadghiri YZ, Douadi M, Sigurdsson EM, Li YS, Quartermain D, Banerjee P, Wisniewski T: Memantine leads to behavioral improvement and amyloid reduction in Alzheimer's-disease-model transgenic mice shown as by micromagnetic resonance imaging. J Neurosci Res 2008, 86:2784-2791

50. Cullen WK, Suh YH, Anwyl R, Rowan MJ: Block of LTP in rat hippocampus in vivo by beta-amyloid precursor protein fragments. Neuroreport 1997, 8:3213-3217

51. Lambert MP, Barlow AK, Chromy BA, Edwards C, Freed R, Liosatos M, Morgan TE, Rozovsky I, Trommer B, Viola KL, Wals P, Zhang C, Finch CE, Krafft GA, Klein WL: Diffusible, nonfibrillar ligands derived from Abeta1-42 are potent central nervous system neurotoxins. Proc Natl Acad Sci USA 1998, 95:6448-6453

52. Walsh DM, Klyubin I, Fadeeva JV, Cullen WK, Anwyl R, Wolfe MS Rowan MJ, Selkoe DJ: Naturally secreted oligomers of amyloid beta protein potently inhibit hippocampal long-term potentiation in vivo. Nature 2002, 416:535-539

53. Unger C, Svedberg MM, Yu WF, Hedberg MM, Nordberg A: Effect of subchronic treatment of memantine, galantamine, and nicotine in the brain of Tg2576 (APPswe) transgenic mice. J Pharmacol Exp Ther 2006, 317:30-36

54. Tseng BP, Green KN, Chan JL, Blurton-Jones M, LaFerla FM: Abeta inhibits the proteasome and enhances amyloid and tau accumulation. Neurobiol Aging 2008, 29:1607-1618

55. Ferrer I, Barrachina M, Puig B: Anti-tau phospho-specific Ser262 antibody recognizes a variety of abnormal hyper-phosphorylated tau deposits in tauopathies including Pick bodies and argyrophilic grains. Acta Neuropathol 2002, 104:658-664

56. Engel T, Goni-Oliver P, Lucas JJ, Avila J, Hernandez F: Chronic lithium administration to FTDP-17 tau and GSK-3beta overexpressing mice prevents tau hyperphosphorylation and neurofibrillary tangle formation, but pre-formed neurofibrillary tangles do not revert. J Neurochem 2006, 99:1445-1455

57. Caccamo A, Oddo S, Tran LX, LaFerla FM: Lithium reduces tau phosphorylation but not $A$ beta or working memory deficits in a transgenic model with both plaques and tangles. Am J Pathol 2007, 170:1669-1675

58. Ma QL, Lim GP, Harris-White ME, Yang F, Ambegaokar SS, Ubeda OJ, Glabe CG, Teter B, Frautschy SA, Cole GM: Antibodies against beta-amyloid reduce Abeta oligomers, glycogen synthase kinase3 beta activation and tau phosphorylation in vivo and in vitro. J Neurosci Res 2006, 83:374-384 